\title{
Chapter 7 \\ Standard Setting Organizations \\ and Competition Laws: Lessons \\ and Suggestions from the United States
}

\author{
Donald E. Knebel
}

\section{Introduction}

As is now well known, more and more of the products people rely upon every day depend on so-called "standards" to assure they operate correctly and with products of other manufacturers. ${ }^{1}$ Standards can be established over time by the competitive process, as consumers opt for one design over others. Consumer preference for the VHS format for video recorders over the Betamax format, eventually leading to VHS becoming the "de facto" standard, is a frequently-cited example. ${ }^{2}$ Waiting for consumers to settle on a standard can be time consuming and inefficient because consumers can end up with useless products, as they did when producers stopped making video recordings in the Betamax format. ${ }^{3}$ As a result, "[s]tandard-setting

\footnotetext{
${ }^{1}$ Standards are particularly important for products and services, such as telephones, that exhibit so-called "network effects," in which the value of the product or service increases with the number of other users or products that can be used with it.

${ }^{2}$ U.S. Dep't of Justice \& Fed. Trade Comm'n. (2007). Antitrust enforcement and intellectual property rights: promoting innovation and competition, $34 \mathrm{n} .6$, available at https://www.ftc.gov/ sites/default/files/documents/reports/antitrust-enforcement-and-intellectual-property-rights-

promoting-innovation-and-competition-report.s.department-justice-and-federal-trade-commission/ p040101 promotinginnovationandcompetitionrpt0704.pdf.

${ }^{3} I d$., at 34 ("By agreeing on an industry standard, firms may be able to avoid many of the costs and delays of a standards war, thus substantially reducing transaction costs to both consumers and firms.").
}

D.E. Knebel $(\bowtie)$

Of Counsel Barnes \& Thornburg LLP, Indianapolis, IN, USA

e-mail: Donald.Knebel@btlaw.com

D.E. Knebel

Indiana University Maurer School of Law, Bloomington, IN, USA

(C) The Author(s) 2018

A. Bharadwaj et al. (eds.), Complications and Quandaries in the ICT Sector,

https://doi.org/10.1007/978-981-10-6011-3_7 
organizations (henceforth "SSOs") represent the most common vehicle to develop industry standards.",

Although SSOs and their procedures and operations vary, standards for a new product or service are typically set by representatives of companies producing or selling a particular type of product, such as a smart phone or a wireless router, which requires the standard. ${ }^{5}$ The representatives consider various possible features or characteristics for the standard, often suggested by one or more of them. The period of consideration of alternative technologies and features, before the final determination of the standard, is commonly referred to as "ex ante." The representatives then vote on proposed standards. After the determination of a standard, considered "ex post," manufacturers can then produce and/or sell devices that conform to this standard.

One or more of the features included in a standard are often covered by patents, typically owned by one or more of the companies participating in the standard-setting process. As a result, practicing the invention claimed in that patent becomes essential to the standard, resulting in a "standard-essential patent" or "SEP." Manufacturers and sellers of products or services conforming to the standard must obtain a license from the owner of the SEP to avoid charges of patent infringement.

This collective standard-setting process creates the possibility that the owner of an essential patent will gain the ability to engage in what is seen as anticompetitive and anti-consumer behavior by charging excessive royalties. As the Ninth Circuit Court of Appeals recently stated:

\begin{abstract}
The development of standards thereby creates an opportunity for companies to engage in anti-competitive behavior. Most notably, once a standard becomes widely adopted, SEP holders obtain substantial leverage over new product developers, who have little choice but to incorporate SEP technologies into their products. Using that standard-development leverage, the SEP holders are in a position to demand more for a license than the patented technology, had it not been adopted by the SSO, would be worth. The tactic of withholding a license unless and until a manufacturer agrees to pay an unduly high royalty rate for an SEP is referred to as "hold-up. ${ }^{6}$
\end{abstract}

" $[\mathrm{H}]$ oldup is of particular concern when the patent itself covers only a small piece of the product...." Under those circumstances, a seller may succumb to demands for royalties that are excessive compared to the value of the patent to preserve the potential profits from sales of the product in light of the costs of litigation and the threat of an injunction against continued sales.

In an effort to prevent owners of SEPs from demanding excessive royalties after a standard has been determined, the "vast majority" of SSOs now require

\footnotetext{
${ }^{4}$ Valerio Torti, Intellectual Property Rights And Competition In Standard Setting, 48 (2016).

${ }^{5}$ One procedure is outlined in the Operations Manual of the Institute of Electrical and Electronics Engineers, Inc. (2015), available at http://standards.ieee.org/develop/policies/opman/sb_om.pdf.

${ }^{6}$ Microsoft Corp. v. Motorola, Inc., 795 F.3d 1024, 1030-31 ( $9^{\text {th }}$ Cir. 2015).

${ }^{7}$ Mark Lemley \& Carl Shapiro, Patent Holdup and Royalty Stacking, 85 Tex. L. Rev. 2009 (2007).
} 
participants either to license those patents royalty free to anyone using the standard or to license them on what have become known as "RAND" or "FRAND" terms. ${ }^{8}$ The two terms, which have identical meanings, ${ }^{9}$ require owners of SEPs participating in standard setting to commit to license those patents to anyone practicing the standard on [Fair], Reasonable And Non-Discriminatory terms.

A recent Discussion Paper prepared by the Government of India states that RAND commitments "ensur[e] that the holder of SEPs should not abuse the dominant market position it gains from widespread adoption of a voluntary technical standard." 10 Unfortunately, that statement may well be overly optimistic. Experience has shown that RAND standards may be "ineffectual" holdups because they are "intentionally vague."12 Vague RAND commitments can also create anticompetitive results by concealing from the standard-setting process the actual costs of incorporating a patented feature into a standard.

Various procedures have been suggested for avoiding holdups and making the standard-setting process more responsive to economic issues. The simplest procedure allows or even requires the participants in the process to declare ex ante the maximum royalty rates and other license terms they would demand for their SEP should it be accepted into the standard. Ironically, as seems to be the case in the Discussion Paper, the primary justification for RAND commitments instead of more open discussion of royalty rates is a desire to avoid running afoul of antitrust and similar competition laws. ${ }^{13}$ At least as interpreted by some, those "antitrust rules may unduly restrict SSOs even when those SSOs are serving procompetitive ends." $" 14$

The possibilities of holdup and other anticompetitive consequences of the standard-setting process are gaining increasing global attention because "[s]tandards that incorporate patented technologies are the backbones of rapidly expanding worldwide markets in the information and communications technology (ICT) sector, such as global smartphone markets that have nearly tripled in size since

\footnotetext{
${ }^{8}$ Mark Lemley \& Carl Shapiro, A Simple Approach to Setting Reasonable Royalties for Standard Essential Patents, 28 Berkeley Tech. L. J. 1136 (2013).

${ }^{9}$ Apple Inc. v. Motorola Inc., 869 F. Supp. 2d 901, 911-12 (N. D. Ill. 2012) ("the word 'fair' adds nothing to 'reasonable' and 'non-discriminatory'"), reversed on other grounds, 757 F.3d 1286 (Fed. Cir. 2014).

${ }^{10}$ Government of India Department of Industrial Policy and Promotion Ministry of Commerce \& Industry, Discussion paper on standard essential patents and their availability on FRAND terms, 9 (2016), available at http://www.ipindia.nic.in/Whats_New/standardEssentialPaper_01March2016. pdf [hereinafter DIPP].

${ }^{11}$ Skitol, Concerted Buying Power: Its Potential for Addressing the Patent Holdup Problem in Standard Setting, 72 ANTITRust L. J. 733 (2005).

${ }^{12}$ Wright, SSOs, FRAND, and Antitrust: Lessons from the Economics of Incomplete Contracts, 10 , (September 12, 2013), available at https://www.ftc.gov/sites/default/files/documents/public_ statements/ssos-frand-and-antitrust-lessons-economics-incomplete-contracts/130912cpip.pdf.

${ }^{13}$ DIPP, supra note 10 , at 8 .

${ }^{14}$ Mark Lemley, Intellectual Property Rights and Standard-Setting Organizations, 90 CALIF. L. Rev. 1895 (2002).
} 
2009." 15 As a result, the experiences in the United States may be helpful as India and other countries deal with these issues. ${ }^{16}$

This chapter will examine the causes of holdups and methods, including RAND commitments, that have been used in the United States to try to avoid them. It will look at possible anticompetitive consequences of RAND commitments and investigate whether antitrust and competition laws, properly understood and applied, require such vague and potentially anticompetitive commitments. It will look at ex ante disclosure of royalty rates and whether competition laws should allow SSOs to require such disclosures or merely allow them. It will conclude that competition laws do not require RAND commitments and should be interpreted to allow SSOs to require ex ante disclosure and discussion of royalty rates so long as certain precautions are implanted to avoid legitimate antitrust concerns.

\section{The Holdup Problem}

\subsection{Disclosure of Standard-Essential Patents}

\section{Anticompetitive Consequences of Failure to Disclose}

A holdup can occur when the owner of a standard-essential patent demands what can be considered an excessive royalty for using the claimed invention after a company has invested in creating products including the standard. At that point, producers and sellers must (1) give in to the demands of the patent owner, (2) face expensive litigation, or (3) give up their investment. Efforts to eliminate holdups focus on eliminating these troubling and potentially anticompetitive choices.

The easiest way for a holdup to occur is for a participant in the standard-setting process to fail to disclose in a timely manner ${ }^{17}$ that it has a patent covering an element of the standard being considered. Had the patent been disclosed before the determination of the standard, the SSO might not have included the feature covered by the patent. The SSO could either have eliminated the feature altogether or selected a version not covered by any patent or covered by a patent requiring a

\footnotetext{
${ }^{15}$ Edith Ramirez, Standard-essential patents and licensing: an antitrust enforcement perspective 1, (September 10, 2014), available at https://www.ftc.gov/system/files/documents/public_statements/ 582451/140915georgetownlaw.pdf.

${ }^{16}$ Kirti Gupta, FRAND in India: emerging developments, Antitrust in Emerging and Developing Countries - Conference Papers 1 (March 1, 2016) ("What policies India implements and how the jurisprudence evolves is of key importance towards the long term prospects of the wireless and telecommunications technologies that heavily rely on the creation and use of common technology standards.”), available at http://papers.ssrn.com/sol3/papers.cfm?Abstract_id=2771465.

${ }^{17}$ The patent must be disclosed sufficiently early in the process so that it can be taken into account along with other patents and features. See Ferrell, J., et al., Standard setting, patents, and hold-up, 74 Antitrust L. J. 624 (2007) ("Patent hold-up often arises when participants learn too late about patents essential to the standard.").
} 
lower royalty. As a result of this obvious opportunity for holdups, many SSOs require participants to disclose patents known to cover a feature being considered for a standard. ${ }^{18}$

A failure to disclose a patent incorporated into a standard can have anticompetitive consequences. If the holder of an SEP can dictate the costs of using that patent, the price to consumers will inevitably rise more than the value of the patent. $^{19}$

\section{Use of Antitrust Laws to Police Non-disclosure}

Because of the potential anticompetitive consequences of the failure of an SSO participant timely to disclose a patent essential to a standard, U.S. antitrust laws have been used to police situations involving such non-disclosure. The results to date have been mixed.

In 1996, the Federal Trade Commission (henceforth "FTC"), which has the power to enforce American antitrust laws, settled a case against Dell Computer Corporation. ${ }^{20}$ According to the allegations, Dell had participated in developing a standard for a computer data bus design without disclosing that it held a patent covering that design and certifying to the SSO that the standard would not infringe any Dell patents. After the standard was approved, Dell asserted that practicing the standard did, in fact, infringe its patent. The FTC alleged that if Dell had disclosed its patent during the standard-setting process, the SSO would have selected a different, unpatented, design for the standard. The FTC alleged that the action of Dell unreasonably restrained competition by, among other things, creating delays and uncertainty in the implementation of the standard. Without admitting liability, Dell settled the case by agreeing not to enforce its patent against anyone using the adopted standard.

Liability under American antitrust laws for actions that are not illegal per $\mathrm{se}^{21}$ usually requires the unlawful creation of significant market power. ${ }^{22}$ It was therefore important to the claim in the Dell case that, by adopting the standard, the SSO "effectively conferred market power upon Dell as the patent holder," which could have been avoided if, with knowledge of Dell's patent, "it could have chosen an equally effective, non-proprietary standard." 23 Consequently, the result can be different if the SSO would not have chosen a different standard even if the SEP had been disclosed.

\footnotetext{
${ }^{18}$ Lemley, supra note 14 , at 1904.

${ }^{19}$ Id. at 1930 ("It is certainly feasible for an IP owner to gain a market advantage by concealing its IP rights from an SSO long enough for the SSO to adopt a standard. And where adoption of the standard is likely to determine the way the market develops, one wielding to control that standard may ultimately control the market.").

${ }^{20}$ In re Dell Computer Corp., 121 F.T.C. 616 (1996).

${ }^{21}$ See United State v. Socony-Vacuum Oil Co., 310 U.S. 150 (1950).

${ }^{22}$ See Northwest Wholesale Stationers, Inc. v. Pacific Stationery \& Printing Co., 472 U.S. 284 (1985).

${ }^{23}$ In re Dell, supra note 20 , at 624 n. 2.
} 
For example, a decision of the FTC finding liability against Rambus, Inc. based on its failure to disclose an SEP was reversed. ${ }^{24}$ The court held that the FTC did not rule out the possibility that the SSO would have selected the patented feature "even if Rambus had disclosed its intellectual property." "25 In reaching this result, the court stated: "[A]n antitrust plaintiff must establish that the standard-setting organization would not have adopted the standard in question but for the misrepresentation or omission., 26

Because of the requirements for establishing an antitrust claim, even a deliberate failure to disclose an SEP might not be sufficient. As one author recently wrote: "[i] $\mathrm{n}$ case there is no evidence of harm to the competitive process (e.g., if the standard-setting organization (SSO) could not select an alternative technology), the IP owner may escape antitrust liability" even for "pure exploitive abuses."27

The potential limitation of antitrust law does not mean that victims of a failure to disclose an SEP are without remedies. Other doctrines, including estoppel, can be used to prevent the owner of an SEP from profiting from an intentional failure to disclose. ${ }^{28}$ What it does mean is that competition laws, to the extent they require proof of an increase in market power, may not be particularly effective in dealing with failures to disclose an SEP.

\subsection{RAND Commitments}

\section{RAND Commitments as Holdup Solution}

However effective may be efforts to police the non-disclosure of SEPs, under the antitrust laws or otherwise, timely disclosure of a patent that might be essential to a standard is not by itself sufficient to avoid holdups. ${ }^{29}$ After a standard has been established that requires use of a disclosed patented feature, manufacturers and sellers of products conforming to the standard must still obtain a license to use the patent or face the threat of potentially expensive and protracted legal action. At that time, especially if they have invested in development of the product and perhaps established a market, the patent owner is often in a position to demand what might

\footnotetext{
${ }^{24}$ Rambus, Inc. v. FTC, 522 F.3d 456, 466 (D.C. Cir. 2008).

${ }^{25} I d$., at 466 .

${ }^{26} I d$., quoting $2 \mathrm{H}$. Hovenkamp et al., Intellectual Property and Antitrust $\S 35.5$ at $35-45$ (Supp. 2008).

${ }^{27}$ TORTI, supra note 4 , at 13 .

${ }^{28}$ Lemley, supra note 14, at 1919 and cases cited at note 105.

${ }^{29}$ E.g., Thomas F. Cotter, Patent Holdups, Patent Remedies, and Antitrust Responses, J. CORP. L., 34, 1201 (2009) ("Disclosure policies alone do not require patentees to refrain from charging supra competitive licensing fees, and a commitment merely to charge a reasonable and nondiscriminatory royalty can be vague.").
} 
be considered an excessive royalty even if the patent was disclosed before the standard was adopted. ${ }^{30}$

Requiring that participants in the standard-setting process agree to license any SEPs on RAND terms was originally seen as a solution to the holdup problem with disclosed patents. The essential idea was that if royalties demanded of the user of a standard were required to be "fair and reasonable," owners of SEPs would not be able to charge excessive royalties. That appears to be the view of the Indian Government in its Discussion Paper. ${ }^{31}$ That view seems to have been, at the very least, optimistic.

Experience in the United States has shown that "[w]hen disputes occur, they reveal a stark disparity of views on the meaning of FRAND obligations." ${ }^{32}$ What may seem a fair and reasonable royalty to the patent owner may seem excessive to the user of the standard. On the other hand, what may seem fair and reasonable to the user of the standard may seem grossly inadequate to the patent owner. For example, in a dispute between Microsoft and Motorola involving standards for video coding and wireless local networks, the parties' respective views of the amount of royalty required by a RAND commitment differed by a factor of $100 .^{33}$

Courts or arbitrators can, of course, determine what is fair and reasonable in any particular case and have done so. But the process can be extraordinarily time consuming and expensive. In what may be an extreme example, the dispute between Microsoft and Motorola over the meaning of RAND took more than five years to resolve. In determining the amount of royalty due for infringement of Motorola's patents, the trial court took testimony from 18 witnesses and ultimately issued a 207-page order explaining the basis for its royalty determination. ${ }^{34}$ Academic literature shows the complexity of the process even in the typical case. ${ }^{35}$

What is fair and reasonable in the context of an SEP is no more certain or easily ascertainable than the ordinary standard for determining a "reasonable royalty" in a typical patent case. As anyone who has litigated patent infringement cases knows, determining what is reasonable in a particular case is often as difficult and expensive as determining infringement and validity. One common test for determining a reasonable royalty requires consideration of up to fifteen different factors. ${ }^{36}$

\footnotetext{
${ }^{30}$ John J. Kelly \& Daniel I. Prywes, A Safety Zone for the Ex Ante Communication of Licensing Terms at Standard-Setting Organizations: The Antitrust Source, ABA 2 (Mar., 2006), available at http:// www.americanbar.org/content/dam/aba/publishing/antitrust_source/Mar06_Prywes3_22f.pdf.

${ }^{31}$ DIPP, supra note 10 , at 9 .

${ }^{32}$ Daryl Lim, Standard Essential Patents, Trolls, And The Smartphone Wars: Triangulating The End Game, 119 Penn State L. Rev. 5 (2014).

${ }^{33} I d$. at 4; Microsoft Corp. v. Motorola, Inc., 795 F.3d 1024, 1032-33 ( $9^{\text {th }}$ Cir. 2015).

${ }^{34} I d$. at 1033.

${ }^{35}$ Anne Layne-Farrar, Pricing Patents for Licensing in Standard-Setting Organizations: Making Sense of FRAND Commitments, 74 ANTITRust L. J. 671 (2007).

${ }^{36}$ The test is based on Georgia-Pacific Corp. v. United States Plywood Corp., 318 F. Supp. 1116 (S.D.N.Y. 1970), mod. and aff'd, 446 F.2d 295 (2d Cir. 1971), cert. denied, 404 U.S. 870 (1971). Not all of these factors may be required to determine a RAND royalty. Microsoft
} 
In 2005, the Assistant Attorney General in charge of the Antitrust Division of the United States Department of Justice (henceforth “Antitrust Division”) said that RAND commitments are only a "partial solution" to the holdup problem because "[a] difficulty of RAND... is that parties tend to disagree later about what level of royalty rate is "reasonable.", 37 That same year, the Chairman of the FTC said in a speech that "[e]xperience has shown, however, that some agreements on RAND rates can be vague and may not fully protect industry participants from the risk of hold up." 38 In 2013, a succeeding Chairman noted the less than clear "meaning of a F/RAND commitment or, for that matter, how one should go about ascertaining that meaning." 39 The author of a recent book on competition in the standard-setting process concludes: "A (F)RAND licensing model probably asks more questions than it answers, and cannot represent the optimal solution" to the holdup problem. ${ }^{40}$

In sum, there is growing support for the conclusion that RAND commitments are not the complete solution ${ }^{41}$ to the holdup problem. ${ }^{42}$

(Footnote 36 continued)

Corp. v. Motorola, Inc., 795 F.3d 1024, 1041 (9 $9^{\text {th }}$ Cir. 2015); Ericsson, Inc. v. D-Link Systems, Inc., 773 F.3d 1201, 1230 (Fed. Cir. 2014). The applicable factors are fact dependent and usually require expert testimony to resolve, making the process lengthy and its outcome uncertain.

${ }^{37}$ Pate, Competition and Intellectual Property in the U.S.: Licensing Freedom and the Limits of Antitrust, 9, (June 3, 2005), available at https://www.justice.gov/atr/public/speeches/209359.pdf.

${ }^{38}$ Deborah Platt Majoras, Recognizing the Procompetitive Potential of Royalty Discussions in Standard Setting, 5-6, (September 23, 2005), available at https://www.ftc.gov/sites/default/files/ documents/public_statements/recognizing-procompetitive-potential-royalty-discussions-standardsetting/050923stanford.pdf.

${ }^{39}$ Wright, supra note 12 , at 8 . In the immediately preceding sentence, Chairman Wright said: "It is well understood that the F/RAND commitment can help minimize the risk of patent hold-up." Id. Chairman Wright did not explain how both sentences could be true.

${ }^{40}$ TORTI, supra note 4 , at 96 .

${ }^{41}$ Some commentators have argued that RAND obligations can reduce the risk of holdups because they represent an irrevocable commitment not to seek an injunction against patent infringement, but instead to negotiate in good faith over the amount of royalties to be paid. E.g., Miller, J. (2007). Standard setting, patents, and access lock-in: RAND licensing and the theory of the firm. Ind. L.R., 40, 358. However, RAND commitments do not, ipso facto, guarantee that injunctions will not be granted to prevent infringement of SEPs. Apple Inc. v. Motorola Inc., 757 F.3d 1286, 1331 (Fed. Cir. 2014); U.S. Dep’t of Justice and U.S. Patent \& Trademark Office. (January 8, 2013). Policy statement on remedies for standards-essential patents subject to voluntary F/RAND commitments, 7 ("That is not to say that consideration of the public interest factors set out in the statute would always counsel against the issue of an exclusion order to address infringement of a F/RAND-encumbered, standards-essential patent."), available at https://www.justice.gov/sites/ default/files/atr/legacy/2014/09/18/290994.pdf.

${ }^{42}$ Not everyone agrees that holdups have been proven to be a significant problem in standard setting. E.g., Gregory J. Sidak, The Antitrust Division's Devaluation of Standard-Essential Patents, 104 The Georgetown L. J. Online 61. 


\section{Potential Anticompetitive Consequences of RAND Commitments}

Not only do mandated RAND commitments not solve the holdup problem, they also create the possibility for additional anticompetitive behavior and outcomes. In the first place, the uncertainty over the meaning of RAND commitments can itself create "considerable delays in the implementation of standardized technology." 43 For example, the Institute of Electrical and Electronics Engineers, Inc. (henceforth "IEEE"), which often engages in standard-setting activities, has concluded that "ambiguities in RAND commitments can lead to litigation that can delay the introduction of standardized products." 44 During that period of uncertainty, the public is deprived of the product or service incorporating the standard and the producer or seller has an incentive to settle the dispute at an excessive royalty just to get its product on the market.

In addition, the inherent vagueness of RAND commitments can distort the standard-setting process. SSOs are forced to select among proposed features and patents for a standard without knowing their respective costs. The entire standard-setting process is intended to determine which combination of features is most attractive to manufacturers and ultimately to consumers. As one author, who ironically seems to be a proponent of RAND commitments, states: "[i]f it is to succeed, the standard-setting process entails evaluating a participant's contributions and suggestions primarily on their technical, practical merit (including cost-effectiveness), rather than on the identity of the firm she represents in the standard-setting process." 45 As IEEE has noted, lack of knowledge of royalty terms ex ante "prevents its members from making 'sensible cost-benefit comparison' when voting on competing technological proposals." 46 Without knowing what any feature might cost in the way of royalties to the owner of an SEP, making an informed choice of a standard based on cost-effectiveness is impossible.

It is often said that during the standard-setting process, "technologies compete to be the standard." 47 It is a strange type of competition that does not involve a consideration of the respective costs of various options. Being forced to choose among possible standards without knowing their respective costs is akin to choosing between competing models of automobiles without knowing their respective sales prices until after the choice has been made or learning the price of a

\footnotetext{
${ }^{43}$ TORTI, supra note 4, at 95. See Broadcom Corp. v. Qualcomm Inc., 501 F.3d 297 (3d Cir. 2007) (failure of owner of SEP to license on what user asserts is required by RAND commitment can lead to holdup).

${ }^{44}$ Letter from Thomas O. Barnett to Michael A. Lindsay 4 (April 30, 2007), available at https:// www.justice.gov/archive/atr/public/busreview/222978.htm.

${ }^{45}$ Miller, supra note 41 , at 365 (emphasis added).

${ }^{46}$ Letter, supra note 44 , at 4.

${ }^{47}$ E.g., Majoras, supra note 38 , at 3.
} 
piece of art after becoming the winning bidder. ${ }^{48}$ No system can be expected to operate rationally in such an environment.

Because of their ambiguity, RAND commitments do not really solve the holdup problem, which itself can lead to higher consumer costs. In addition, RAND commitments do not allow economically rational selection of a standard, which can also lead to economic inefficiencies. If no other possibilities existed for making the standard-setting process more effective in eliminating holdups and enabling an evaluation of the cost effectiveness of a proposed standard, the problems with RAND commitments would be unavoidable.

There are other possibilities, including requiring, or at least allowing, owners of potential SEPs to disclose ex ante the maximum royalty rate and other license terms they would demand from users if their patent were included in the standard. ${ }^{49}$ Such disclosures would solve both problems inherent in RAND commitments. They would prevent owners of SEPs from demanding ex post royalties in excess of what they could demand ex ante and would allow SSOs to take prospective royalty costs into account in determining a standard. Ironically, the reason such disclosures are not typical in the standard-setting process is said to be the antitrust and similar competition laws that are intended to eliminate the very problems created by the vague RAND requirements.

\section{Antitrust Explanations for RAND Commitments}

As authors involved in the standard-setting process write: "SSO members fear, with justification, that any communications with patent holders during the standards development process regarding the latter's royalty demands can expose the SSO and its participants to antitrust claims." 50 To avoid antitrust problems, SSOs are typically advised to avoid any discussion of the "[v]alidity of patents or the costs of using them." As a result, "some SSOs expressly forbid discussion of [royalty rate] issues when a standard is under consideration, presumably for fear of antitrust liability." ${ }^{, 52}$ In 2005, the Chairman of the FTC reported that because of antitrust

\footnotetext{
${ }^{48}$ See Jorge Contreras, Technical Standards and ex ante Disclosure: Results and Analysis of an Empirical Study, 53 JuRIMETRICS J. 164 (2013) ("When I go to my neighborhood diner and open the breakfast menu, I expect to see a price listed for each entrée, beverage, and side dish. Deciding what to order would be more difficult if I didn't have this pricing information.").

${ }^{49}$ Kelly \& Prywes, supra note 30 , at 8 ("The mere disclosure of royalty demands, with nothing more, will reduce some of the uncertainty in the standards selection process.").

${ }^{50} I d$. at 1. Accord, e.g., Skitol, supra note 11, at 734 ("SSOs fret that 'concerted' consideration of license terms during standard setting would expose all participant to 'buyer cartel' antitrust allegations.").

${ }^{51}$ Jennifer L. Gray, Antitrust Guidelines for Participating in Standard Setting Efforts, Corporate Counseling Report (Newsletter of the Corporate Counseling Committee of the Antitrust Section of the ABA) (Spring 2001) 8.

${ }^{52}$ Lemley, supra note 14, at 1965.
} 
concerns, "some SSOs and their participants have hesitated to allow unilateral announcements of royalty rates by, let alone ex ante joint royalty rate discussions with, firms that own the technology being considered for incorporation into the standard, settling instead for rules that demand RAND terms for members." Noting that the "antitrust concerns are understandable," she lamented that "they may have unduly prevented announcements of pricing intentions or royalty discussions that may, in fact, provide procompetitive benefits." 54

Professor Shapiro also noted the irony in the claim that the antitrust laws may be leading to the very evils they were designed to attack:

Unfortunately, antitrust concerns have led at least some of these bodies to steer clear of such ex ante competition, on the grounds that their job is merely to set technical standards, not to get involved in prices, including the terms on which intellectual property will be made available to other participants. The ironic result has been to embolden some companies to seek substantial royalties after participating in formal standard setting activities. ${ }^{55}$

"Perversely, by leaving the precise licensing terms vague, this caution can in fact lead to ex post holdup by particular rights holders, contrary both to the goal of enabling innovation and to consumers' interests."

The notion that competition laws require the use of vague RAND commitments in lieu of specific royalty demands has made its way to India. In its recent Discussion Paper, the Indian Department of Industrial Policy and Promotion, Ministry of Commerce and Industry, attributed the use of RAND commitments to a desire "to avoid any competition concerns." 57

If vague RAND commitments are required for SSOs to remain compliant with antitrust laws and similar competition laws, their anticompetitive effects, perverse as they may be, might be unavoidable. But before Indian competition law authorities go down the RAND-only path and do not allow disclosure and discussion of actual royalty rates and other important licensing terms, it is essential to determine if India's competition laws really require such a potentially anticompetitive result. In that connection, it is useful to look at the American antitrust laws and what the enforcement authorities have said about those laws and their limitation on the disclosure and discussion of specific royalty information.

\footnotetext{
${ }^{53}$ Majoras, supra note 38, at 6 .

${ }^{54} I d$. at 7 .

${ }^{55}$ Carl Shapiro, Navigating the Patent Thicket: Cross Licenses, Patent Pools, and Standard Setting, NBER 142, (2001), available at http://www.nber.org/chapters/c10778.pdf.

${ }^{56} I d$. at 128 .

${ }^{57}$ DIPP, supra note 10 , at 8 .
} 


\section{Do U.S. Antitrust Laws Require Vague Royalty Commitments?}

The claimed concern that the antitrust laws might prohibit SSOs from asking participants the royalty rates they would charge if their SEPs were required to practice a proposed standard is curious, to say the least. After all, the very nature of any SSO is for competitors to reach an agreement on which several competing technologies should be used by them in the future. That selection inevitably affects the costs their companies will have to pay to use the standard and the costs that consumers will have to pay for products including it. Antitrust policy not only tolerates these agreements among competitors, but actually encourages them, because of their "procompetitive benefits." 58 It would be a strange result if an agreement requiring certain features in a proposed standard, potentially imposing added costs on consumers, is legal, but considering those costs during the standard-setting process is not.

In addition, some SSOs require participants to agree to license SEPs they own royalty free to anyone using an adopted standard. ${ }^{59}$ As stated by the former Chairman of the FTC, "SSOs that require members to license incorporated technology to each other royalty-free have already, in effect, collectively negotiated a royalty arrangement." 60 If actual agreements requiring a uniform royalty rate of zero are lawful, no rational antitrust policy should make it unlawful for SSOs to allow, or even require, patent owners, to state, without prior agreement, the non-zero royalty rates they would demand should their technology be included in the proposed standard.

Finally, the entire objective of RAND commitments is to reduce holdups by placing limits on the royalties that can be charged for patents required by a standard. To the extent those commitments accomplish that objective (which is doubtful), ${ }^{61}$ there is no basis for concluding an agreement to require every participant to charge RAND royalties is legal while one allowing or requiring that participants state their specific royalty demands in advance of the standard being selected is not. ${ }^{62}$

These anomalies may not be important if, as some have suggested, the antitrust laws prohibit even the mention of royalty rates during the standard-setting process. ${ }^{63}$ What is therefore needed is an examination of those laws in the context of standard setting.

\footnotetext{
${ }^{58}$ Golden Bridge Technology, Inc. v. Motorola, Inc., 547 F.3d 266, 273 (5 ${ }^{\text {th }}$ Cir. 2008).

${ }^{59}$ Lemley, supra note 14, at 1905.

${ }^{60}$ Majoras, supra note 38 , at 8 .

${ }^{61}$ Supra note $10-13$.

${ }^{62}$ Skitol, supra note 11, at 737 ("Specifically, if it is lawful for an SSO to insist on commitments to RAND terms during standard setting, how does it then become unlawful for the same SSO to insist (also during the standard-setting process) on a clear explanation of what RAND will mean as applied to a particular patent being offered for a proposed standard under consideration?").

${ }^{63}$ Supra note $16-18$.
} 


\subsection{Relevant Antitrust Principles}

SSOs, by their very nature, require agreements among competitors. As a result, "any agreement on the part of SSO members is potentially subject to antitrust scrutiny under Section 1 of the Sherman $\mathrm{Act}^{64}$ as a contract, combination or conspiracy, in restraint of trade." ${ }^{, 65}$ But not all agreements among competitors are violations of the antitrust laws. If they were, SSOs would themselves be illegal, something that no one any longer contends because of their economic benefits. ${ }^{66}$

Agreements by competitors to fix the price of products or services they sell are illegal per se under Section $1 .{ }^{67}$ Because of the danger that even discussions about prices can lead to price fixing, discussions about proposed price terms among competing sellers can also be illegal. ${ }^{68}$

Especially if they are cautious, ${ }^{69}$ SSOs that refuse to allow discussion of proposed royalty terms are not primarily concerned about being charged with price fixing as sellers. Instead, "SSOs fear liability for acting, in effect, as a buyers' cartel that artificially suppresses the price that a patentee can command for access to its technology.,"70

Agreements on price by buyers acting collectively to reduce the prices they pay for products or services are not illegal per se. ${ }^{71}$ Because of their ability to reduce prices to consumers, such agreements among buyers are evaluated under the Rule of Reason, taking into account their purpose and their effect. ${ }^{72}$ No U.S. court has held that merely discussing the price to be paid by a group of competitors is illegal under the antitrust laws and any such conclusion would be irrational. If members of a buying group can lawfully decide to buy only from a particular source at a common price (and they can), they obviously must be able to discuss the various prices offered to them by prospective sellers.

To support their fear of allowing any discussion of royalty rates, SSOs often cite to Sony Electronics, Inc. v. Soundview ${ }^{73}$ in which an SSO and its members, competing television manufacturers, were accused by the owner of an SEP of agreeing to limit to five percent the royalty paid for rights to the SEP. The trial court refused to dismiss the complaint because "[t]he all-or-nothing price [allegedly] set

\footnotetext{
${ }^{64} 15$ U.S.C. $\S 1$.

${ }^{65}$ Cotter, supra note 29 , at 1200 .

${ }^{66}$ Lemley, supra note 14.

${ }^{67}$ United State v. Socony-Vacuum Oil Co., 310 U.S. 150 (1950).

${ }^{68}$ United States v. Container Corp., 393 U.S. 333 (1969).

${ }^{69}$ Supra note $37-38$.

${ }^{70}$ Miller, supra note 41 , at 367.

${ }^{71}$ Northwest Wholesale Stationers, Inc. v. Pacific Stationery \& Printing Co., 472 U.S. 284 (1985).

${ }^{72}$ Id. at 296; see Fed. Trade Comm's \& U.S. Dep't of Justice, Antitrust Guidelines for Collaborations Among Competitors, 14 (2000). ("Competitor collaborations may involve agreements jointly to purchase necessary inputs. Many such agreements do not raise antitrust concerns and indeed may be procompetitive.").

${ }^{73} 157$ F. Supp. 2d 180 (D. Conn. 2001).
} 
by these colluding purchasers can depress the price below the optimal price that would obtain if usual market forces of supply and demand were at work." Because the court ultimately determined that the standard did not require use of the patent, the antitrust claim became moot and was never resolved.

Whatever the merits of the claim in the Sony case, it involved an alleged agreement to fix royalties below their market value after the standard had already been determined. The claim did not involve efforts before the determination of the standard to determine the cost of incorporating a particular patented feature into the standard. The difference is critical. Once a standard has been determined, the cost of using it is not relevant to the SSO, which has already made its decision. The cost at that time is relevant only to those individual companies that need the patent to produce and sell products or services including the standard. On the other hand, before the standard is determined, the royalty costs associated with various features are needed by SSO members in order to determine the most cost-effective standard. ${ }^{75}$

The Sony case does not support the claim that RAND commitments are required by the antitrust laws and that no discussion of royalty rates ex ante by SSO participants is allowed. There simply is no decision even suggesting that discussion of royalties before a standard has been determined is illegal. Of course, the absence of any decision does not rule out the possibility of illegality, so it is important to look at efforts of lawmakers and enforcement authorities to clarify the law applicable to SSOs.

\subsection{The Standards Development Organization Advancement Act}

In 2004, the United States enacted the Standards Development Organization Advancement Act of 2004 (henceforth "Standards Act") to clarify the application of U.S. antitrust laws to formal standard-setting organizations. ${ }^{76}$ Under the Standards Act, activities of standard-setting organizations having specified procedures to protect their objectivity and openness ${ }^{77}$ are judged under the Rule of Reason. ${ }^{78}$ In addition, any recovery for a violation is limited to actual damages and not the treble damages otherwise available to those harmed by antitrust violations. ${ }^{79}$

The Standards Act excludes from its protection "[e]xchanging information among competitors relating to cost, sales, profitability, prices, marketing, or distribution of any product, process, or service that is not reasonably required for the purpose of developing or promulgating a voluntary consensus standard, or using

\footnotetext{
${ }^{74} I d$., at 185 .

${ }^{75}$ Supra note $14-15$.

${ }^{76}$ Pub. L. No. 108-237, 118 Stat. 661 (2004).

${ }^{77} 15$ U.S.C. $\$ 4301(\mathrm{a})(8)$.

${ }^{78} 15$ U.S.C. $\$ 4302(2)$.

${ }^{79} 15$ U.S.C. $\$ 4303(a)$.
} 
such standard in conformity assessment activities. ${ }^{" 80}$ The necessary implication of this exclusion is that discussions of costs and prices that are reasonably related to the determination of a standard are protected by the Standards Act and not subject to per se liability or treble damages. It seems beyond dispute that discussion of proposed royalty rates associated with potential SEPs are reasonably required for an appropriate determination of a standard.

More important, the legislative history of the Standards Act indicates that the Act was intended to "encourage disclosure by intellectual property rights owners of relevant intellectual property rights and proposed licensing terms" and "further encourages discussion among intellectual property rights owners and other interested standards participants regarding the terms under which relevant intellectual property rights would be made available for use in conjunction with the standard or proposed standard." ${ }^{\prime 81}$ Consequently, the Standards Act supports the proposition that ex ante disclosure of royalty terms by members of an SSO are not inconsistent with U.S. antitrust policy.

\subsection{Statements of Antitrust Enforcers}

Although useful in determining antitrust policy, the Standards Act is not a guarantee that discussions of potential royalty rates in the context of standard setting cannot lead to antitrust challenges. In the first place, the Standards Act protects only the SSOs themselves and expressly does not protect "the parties participating in the standards development organization." ${ }^{, 2}$ In addition, even the threat of having the activity judged under the Rule of Reason without treble damage possibilities may be enough to deter even procompetitive discussions of royalty rates during the standard-setting process. ${ }^{83}$ As a result, for more than ten years, U.S. antitrust enforcement authorities have attempted to make clear that participants in a standard-setting process are not prohibited from announcing ex ante the specific royalties they will charge should their patent be required to practice the determined standard. Instead, they have noted that such announcements can make the standard-setting process more competitive and less subject to holdups.

For example, on June 3, 2005, R. Hewitt Pate, the Assistant Attorney General in charge of the Antitrust Division, spoke to an EU Competition Conference in Florence, Italy, about antitrust issues in intellectual property licensing. Referring to the holdup problem in the context of standard setting, he said:

\footnotetext{
${ }^{80} 15$ U.S.C. $\S 4301(a)(8)$.

${ }^{81}$ Cong. Rec. - House. (June 2, 2004), 11280.

${ }^{82} 15$ U.S.C. $\$ 4301(a)(8)$.

${ }^{83}$ Kelly \& Prywes, supra note 30 , at 5 ("The mere possibility of an antitrust challenge, even under a rule of reason standard, inhibits many SSOs from allowing most forms of ex ante royalty communication.").
} 
Increasingly, standards development organizations are requiring "reasonable and non-discriminatory" (RAND) licensing, which is a partial solution. A difficulty of RAND, however, is that parties tend to disagree later about what level of royalty rate is "reasonable." It would be useful to clarify the legal status of ex ante negotiations over price. Some standards development organizations have reported to the Department of Justice that they currently avoid any discussion of actual royalty rates, due in part to fear of antitrust liability. It would be a strange result if antitrust policy is being used to prevent price competition. ${ }^{84}$

Later that year, Deborah Platt Majoras, Chairman of the FTC, gave a speech to a conference discussing antitrust policy governing standard setting. After stating that "RAND rates can be vague and may not fully protect industry participants from risk of hold-up," 85 she expressly noted that "if [SEP] owners stated their royalty rates up front, the price could become part of the competition among technologies for incorporation into the standard." ${ }^{86}$ Noting that "some SSOs and their participants have hesitated to allow unilateral announcements of royalty rates," she pointed out that "patent holder's voluntary and unilateral disclosure of its maximum royalty rate" would not violate Section 1 of the Sherman Act and is "highly unlikely to require antitrust scrutiny." 87 Because collective negotiations on a royalty rate before a standard is determined "can be a sensible way of preventing hold up, which can itself be anticompetitive," and "can increase competition among rival technologies striving for incorporation into the standard at issue," she also announced that such negotiations would be judged under the Rule of Reason. ${ }^{88}$

On October 30, 2006, the Antitrust Division responded to a request for a business review letter ${ }^{89}$ from VITA, an international trade association, and VSO, its standards development subcommittee. ${ }^{90}$ Under their proposed new policy, all members working to develop a standard would be required to disclose all patents or patent applications believed to be essential to a future standard and to specify "the maximum royalty rate (either in terms of dollars or as a percentage of the sales price) as well as the most restrictive non-price licensing terms the VITA member company he or she represents will request for such patent claims that are essential to implement" the eventual standard. ${ }^{91}$ The proposed policy would preclude negotiation or discussion of specific licensing terms among group members.

\footnotetext{
${ }^{84}$ Pate, supra note 37 , at 9.

${ }^{85}$ Majoras, supra note 38 , at 5 .

${ }^{86} \mathrm{Id}$. at 6 .

${ }^{87} I d$. at 7 .

${ }^{88} I d$.

${ }^{89}$ Under the Business Review Procedure of the Antitrust Division, persons interested in conducting certain activities can seek a determination of whether the Division would have the intention of challenging those activities under the antitrust laws. 28 C.F.R. $\$ 50.6$. Although the statement of intention does not bind the Antitrust Division, "[a]s to a stated present intention not to bring an action, however, the Division has never exercised its right to bring a criminal action where there has been full and true disclosure at the time of presenting the request.” 28 C.F.R. §50.6(9).

${ }^{90}$ Letter from Thomas O. Barnett to Robert A. Skitol. (October 30, 2006), available at https:// www.justice.gov/sites/default/files/atr/legacy/2006/10/31/219380.pdf.

${ }^{91} I d$. at 4.
} 
In its analysis, the Antitrust Division noted that the proposed policy would preserve "the benefits of competition between alternative technologies that exist during the standard-setting process." 92 The analysis continued:

Disclosure of [the maximum royalty rates] permits the working group members to make more informed decisions when setting a standard. They might decide, for example, that a cheaper, less technologically elegant solution would be best or they might determine that it is worth including the proffered technological elegance even on the most restrictive terms declared by the patent holder. At a minimum, the disclosure of most restrictive licensing terms decreases the chances that the standard-setting efforts of the working group will be jeopardized by unexpectedly high licensing demands from the patent holder. ${ }^{93}$

As a result of these benefits, the Antitrust Division announced that it had no present intention to take antitrust enforcement action against the proposed requirement that SSO participants disclose their license terms during the standard-setting process. The Antitrust Division also noted that even if the policy were to allow collective negotiation or discussion of royalty rates, "the Division would evaluate any antitrust concerns about them under the rule of reason because such actions could be procompetitive." 94

In April 2007, the Antitrust Division and the FTC issued formal guidelines that incorporated their earlier statements and business review letters. ${ }^{95}$ With respect to $\mathrm{SSO}$, the agencies noted the important difference under the antitrust laws for joint actions directed to selling prices and those directed to the prices paid by buyers. ${ }^{96}$ Any activities of members of SSOs to establish prices as "buyers" of technology would be judged under the Rule of Reason while their activities to fix prices as "sellers" would be considered illegal per se. ${ }^{97}$ Referring to the Antitrust Division's business review letter concerning VITA's requirement that participants in its standard-setting process disclose their most restrictive license terms, the two enforcement agencies said they approved the policy because it "preserved competition between technologies during the standard-setting process." 98

As a result of these statements, it seems clear that the U.S. antitrust laws, at least as interpreted by those charged with enforcing them, should not prohibit SSOs from at least allowing participants in the standard-setting process to disclose their most restrictive licensing terms, including maximum royalty rates, for any patent that could become essential to the standard. ${ }^{99}$ It necessarily follows that the antitrust laws should

\footnotetext{
${ }^{92} I d$. at 9.

${ }^{93} I d$., at 9.

${ }^{94} I d$, at 9 .

${ }^{95}$ U.S. Dep't of Justice \& Fed. Trade Comm'n, supra note 2.

${ }^{96} I d$., at $54-55$.

${ }^{97} I d$.

${ }^{98} I d$.

${ }^{99}$ Unfortunately, despite all the efforts of U. S. enforcement authorities, some SSOs are apparently still avoiding even a discussion of royalty costs for fear of being accused of "unlawful price fixing." Wright, supra note 12, at $10-11$.
} 
not prohibit members of the SSO from taking those terms into account in determining the cost effectiveness of a particular standard. ${ }^{100}$ Indeed, that is the reason for wanting such license terms to be disclosed. If license terms can be considered by SSO participants, it would be foolish to prohibit those participants from discussing those terms during their deliberations to determine the most cost-effective standard features. ${ }^{101}$ In fact, the very title of Chairman Majoras' talk was "Recognizing the Procompetitive Potential of Royalty Discussions in Standard Setting."102

\subsection{Required Disclosure of License Demands}

\section{Different Views about Mandatory Disclosure}

After studying standard-setting practices and competition laws in the European Union and the United States, Valerio Torti, a Post-Doctoral Research Fellow at the Centre for Law and Business of the National University of Singapore, published a book outlining his conclusions about an optimal system for avoiding holdups and rationalizing the process. ${ }^{103}$ As have many others, ${ }^{104}$ he found serious flaws in F/RAND commitments that "undermine the ultimate goal of competition and of any other public policy, which is the enhancement of consumer and societal welfare." 105 He also considered and rejected the idea that SSO members collectively negotiate royalty rates for SEPs, both for practical and legal reasons. ${ }^{106}$ Considering all the relevant issues, including those involving antitrust and competition laws, he concluded that ex ante disclosure of the most restrictive licensing terms, including the maximum royalty to be sought, represents the optimal solution of legal and practical problems in standard setting. ${ }^{107}$

Torti did not advocate that SSOs require that members disclose their proposed license terms before the standard determination. Instead, perhaps sensitive to legal

\footnotetext{
${ }^{100}$ Kelly \& Prywes, supra note 30, at 8 ("During the development process, the SSO and its members may consult with each other and evaluate the estimated cost and technical advantages of different options...").

${ }^{101}$ The IEEE permits members to receive copies of documents including the royalty rate proposals and to include rate information in presentations comparing relative costs of various standards proposals, but prohibits any discussion of the rates. IEEE Standards Association, Understanding patent issues during IEEE standards development (Mar. 2016), available at http://standards.ieee. org/faqs/patents.pdf. Because the distribution of the documents containing the royalty rate proposals effectively communicates them to the members of the SSO, the prohibition on discussion seems pointless and counterproductive.

${ }^{102}$ Majoras, supra note 38.

${ }^{103}$ Torti, supra note 4.

${ }^{104}$ Supra note $9-17$.

${ }^{105}$ Torti, supra note 4 , at $96 . I d$.

${ }^{106} I d$., at $96-105$.

${ }^{107} I d$., at $198-202$.
} 
concerns, his proposed procedure "would consist in a voluntary mechanism for [intellectual property owners] to disclose unilaterally the licensing terms in advance." 108 On the other hand, Professor Lim notes that "[t]he most straightforward method is for all SSOs to impose mandatory disclosure of only patents that are truly 'essential' to the standard, as well as any relevant licensing terms and rates." "109

American antitrust authorities have repeatedly noted the advantages of ex ante disclosure of specific royalty rates as a way of avoiding holdups and making the standard-setting process more able to determine the most cost-effective standards. They have noted the perverse result of claiming that the antitrust laws do not allow such disclosures. But they have been less clear about whether the antitrust laws should be equally tolerant of SSO rules that require disclosures of license terms as they are with rules that merely allow them. ${ }^{110}$ Recent experience suggests that antitrust and competition laws should allow SSOs to require such disclosures.

\section{Experience with Voluntary and Mandatory Disclosure Models}

The Antitrust Division approved VITA's policy of requiring the disclosure of maximum royalty rates and the most restrictive non-royalty terms because it believed that policy "should preserve, not restrict, competition among patent holders." 111 Recent evidence confirms the wisdom of that determination.

Professor Contreras studied VITA's experience under its new policy. ${ }^{112} \mathrm{He}$ concluded that requiring disclosure of proposed license terms during the standard-setting process did not have any of the negative consequences that had been feared, including delaying determination of the standard and affecting the quality of the standard. ${ }^{113}$ The majority of those who had participated in VITA standard setting "felt that the information elicited by the organization's [mandatory] ex ante policy improved the overall openness and transparency of the standards-development process." 114

In addition, based on the available data, Professor Contreras concluded that there was no evidence that "[e]x ante policies will depress royalty rates." 115 Because a reduction in royalty rates is the primary, if not only, fear of ex ante disclosure of royalty rates ${ }^{116}$ this finding is particularly important.

\footnotetext{
${ }^{108} I d$., at 198.

${ }^{109}$ Lim, supra note 32 , at 21 . For a variety of reasons, Professor Lim does not recommend adopting his own "straightforward method." Id., at 22.

${ }^{110}$ Compare U.S. Dep't of Justice \& Fed. Trade Comm'n, supra note 2, at 54 (approving, without limitations, "an IP holder's voluntary and unilateral disclosure of its licensing terms") with Letter, supra note 92 (approving SSO policy requiring disclosure of maximum royalty rates).

${ }^{111}$ Letter, supra note 90 , at 10.

${ }^{112}$ Contreras, supra note 48 , at 164.

${ }^{113} I d$., at 205.

${ }^{114} I d$., at 211 .

${ }^{115} I d$.

${ }^{116}$ Supra note $21-22$.
} 
In 2006, IEEE and its Standards Association (henceforth "IEEE-SA") sought a business review letter about a proposed change to IEEE's policy regarding licensing commitments during their standard-setting activities. ${ }^{117}$ Under their proposed policy, patent holders participating in IEEE-SA standard-setting activities "would have the option to publicly disclose and commit to the most restrictive licensing terms (which may include the maximum royalty rate) they would offer for patent claims that are found to be essential to the standard." 118 The Antitrust Division approved this idea, based on its analysis in connection with VITA. ${ }^{119}$

In 2014, IEEE and IEEE-SA went back to the Antitrust Division, seeking a business review letter for a revised policy. ${ }^{120}$ In their letter, IEEE and IEEE-SA noted that "only two of approximately 40 LOAs [letters setting out commitments with respect to SEPs] that parties have submitted since 2007 have disclosed their most restrictive licensing terms." 121 The proposed new policy sought to give additional definition and clarity to the term "Reasonable Rate," but did not mandate "any specific royalty calculation methodology or specific royalty rates.",

The IEEE experience appears to demonstrate that merely allowing SSO participants to disclose their maximum royalty rates for SEPs does not result in significant disclosures and therefore does not provide the advantages of such disclosures in preventing holdups and allowing the SSO to determine the most cost-effective standard. As a result, requiring disclosure ex ante of licensing terms appears to have pro-competitive benefits and no demonstrable competitive harms.

In addition, at least one basis for the reluctance of patent owners to disclose their license terms ex ante is that uncertainty over the meaning of RAND can actually work to their advantage by allowing them to charge higher royalties should their patents becomes essential to the standard. Said another way, owners of SEPs may actually prefer holdups if they believe their patents will be selected for the standard. As Professor Lemley and Mr. Myhrvold have stated in an analogous context, "the only people who stand to lose from mandatory disclosure of licenses are those who are taking advantage of the current state of ignorance... by holding up defendants...." As a result, Professor Contreras concludes that "unless ex ante disclosures are mandated by an [SSO] policy, patent holders have few incentives to make such disclosures on a voluntary basis." 124

\footnotetext{
${ }^{117}$ Letter, supra note 44.

${ }^{118} I d$., at 4 .

${ }^{119} I d .$, at $9-11$.

${ }^{120}$ Letter from Renata B. Hesse to Michael A. Lindsay, (Feb.2, 2015), available at https://www. justice.gov/sites/default/files/atr/legacy/2015/02/02/311470.pdf.

${ }^{121} I d$., at 4.

${ }^{122} I d$., at 12 .

${ }^{123}$ Mark Lemley \& Nathan Myhrvold, How To Make A Patent Market 36 Hofstra L. Rev. 259 (2007).

${ }^{124}$ Contreras, supra note 48 , at 207.
} 
Based simply on that conclusion, antitrust and similar competition laws should not be interpreted to prohibit SSOs from requiring their members to disclose their maximum royalty rates and other license terms ex ante. If, as most people studying the standard-setting process have concluded, RAND requirements do not completely solve the holdup problem and ex ante disclosures of license terms do, it makes little sense to preclude policies that ensure that those procompetitive disclosures actually occur.

The different experiences of VITA and IEEE provide another, perhaps more important, reason for permitting mandatory disclosures of license terms during the standard-setting process. The VITA solution of required disclosures of maximum royalty rates and other key license terms makes no effort at all to control those rates and terms. Each standard-setting participant is allowed to state ex ante whatever royalty rates it wants and to define whatever it chooses as the base to which those rates are to be applied. Requiring standard-setting participants to state their royalty demands in advance of a standard determination is no more anticompetitive than asking participants in an auction to make their bids in writing and not orally. To the contrary, knowing the royalty and license terms promotes competition among competing standards.

On the other hand, to try to eliminate the holdup problem in the face of the failure of voluntary disclosures of royalty rates, IEEE more precisely defined RAND by, for example, mandating the only base that SSO members could later use in their royalty negotiations. As at least one commentator has observed, this agreement on a royalty base, perhaps the largest subject of disagreement in the context of RAND, can be characterized as "price fixing." ${ }^{125}$ Compared with an agreement by SSO members on important RAND royalty provisions, an agreement merely to require SSO participants to disclose their proposed license terms is much more in keeping with antitrust principles while more likely to overcome the limitations of RAND commitments. ${ }^{126}$

Because of the procompetitive benefits of ex ante disclosure of royalty rates and the possible anticompetitive motives behind the reluctance of SSO participants to disclose those rates in favor of vague RAND commitments, one author has suggested that the failure of SSOs to at least allow disclosures may itself violate the antitrust laws. ${ }^{127}$ Given the benefits of disclosure in preventing holdups and allowing the costs of SEPs to be considered in the standard-setting process, this is not an unreasonable conclusion. However, SSOs and their members may have legitimate reasons not to require ex ante disclosure of license terms, including the

\footnotetext{
${ }^{125}$ E.g., Sidak, supra note 42 , at 50.

${ }^{126}$ Skitol, supra note 11, at 737 ("How is it acceptable for an SSO to fix future royalties at a RAND level but not acceptable for the SSO even to inquire into actual terms, subjecting participants to one-sided individual license negotiations after the standard is in place and the patent holder has thereby acquired ex post market power?").

${ }^{127} I d$. at 729, 738 (“[T]he standard-setting community's continued resistance to considering license terms during the standard-setting process could in itself create significant antitrust exposure.”).
} 
additional costs associated with such disclosures. ${ }^{128}$ As a result, it is premature to suggest that all SSOs must allow or require such disclosures. But that fact provides no reason for interpreting antitrust and competition laws to preclude an SSO from adopting policies allowing or requiring such disclosures if it determines such policies will work best for it. Such policies can make the standard-setting process more competitive and should be encouraged even if not required.

\section{Recommendations}

\subsection{Mandatory Disclosures}

There is little disagreement that RAND disclosures are insufficient, at least under some circumstances, to prevent holdups and that the standard-setting process would be more effective if there were ex ante disclosures of a patent owner's most restrictive licensing terms, including its maximum royalty rate. ${ }^{129}$ Experience to date suggests that only mandatory disclosure requirements will overcome the self-interest of SSO participants to withhold those terms until after the standard is set. ${ }^{130}$ There is little, if any, reason why the antitrust laws should prohibit such mandatory disclosures and many reasons to believe they advance the objectives of the antitrust laws.

Based on the experience in the United States, it would therefore be in the interest of more effective standard setting for Indian competition laws to make clear that a requirement that SSO participants disclose their maximum royalty rates and other license terms before the standard is determined is encouraged and not prohibited. It is also important to make clear that discussing the respective licensing proposals during the standard-setting process is an integral and important part of the process and also does not violate competition laws. The experience of VITA suggests that mandatory disclosure policies can work and do not adversely affect the standard-setting process. At least at this time, there is no need for Indian law to require such disclosures. ${ }^{131}$ Policies requiring disclosures may not be suitable for all SSOs, but competition laws should not preclude their use by SSOs that want to adopt them. ${ }^{132}$

\footnotetext{
${ }^{128}$ Wellford, H. Antitrust Issues in Standard Setting, 2d Annual Seminar on IT Standardization and Intellectual Property (Mar. 29, 2007), available at https://www.justice.gov/atr/speech/antitrustissues-standard-setting.

${ }^{129}$ Supra note $33-34$.

${ }^{130}$ Lemley \& Nathan Myhrvold, supra note 123, at 259 (advocating public disclosure of terms of patent license agreements).

${ }^{131}$ See U.S. Dep't of Justice \& Fed. Trade Comm'n, supra note 2, at 55 ("The Agencies take no position as to whether SSOs should engage in ex ante discussion of licensing terms").

${ }^{132}$ When IEEE went back to the Antitrust Division, it sought additional specificity in the meaning of RAND. Letter, supra note 120 . As previously noted, it makes no sense to allow more and more specific definitions of RAND while prohibiting discussions of specific royalty demands. Lemley, supra note 14 .
} 


\subsection{Precautions}

Just as it is clear that competition laws should not prohibit the requirement of ex ante disclosure of license terms, it needs to be made clear that those laws can be violated if adequate precautions are not taken to make sure the standard-setting process is not corrupted. As a result, it is important that everyone recognize that disclosure of license terms, even if required by an SSO, not be a part of an agreement that otherwise violates the law because of its anticompetitive purpose or effect. First, any agreement among SSO participants on the license terms they will present is likely to be considered illegal price fixing by sellers. Participants therefore must be cautioned not to discuss their proposals with other patent owners before the proposals have become public to all SSO members. It is often thought that "sealed bids," all opened together, can minimize chances for collusion. ${ }^{133}$ Whether participants are allowed to change their proposed terms after seeing other proposals is a detail that can be made based on the desires of the SSO and its members.

In addition to concerns about illegal fixing of licensing terms, any time competitors get together, there is a risk that they will engage in discussions about the prices at which they will sell products or services incorporating the standard. ${ }^{134}$ Standard precautions to prevent illegal discussions include having lawyers at meetings, maintaining minutes, recording meetings, etc. ${ }^{135}$ Those precautions are not specific to SSOs and are known by most sophisticated companies.

\section{Conclusion}

Based on experience in the United States, RAND commitments in the context of standard setting by SSOs are not sufficient to eliminate the possibility for holdups. Because of the procompetitive benefits of ex ante disclosure of specific royalty demands and the anticompetitive implications of precluding such disclosures, it makes no sense for competition laws to (1) prohibit such disclosures, (2) prohibit making such disclosures mandatory or (3) prohibit discussion of royalty demands after they have been presented to the SSO. At this time, it is not necessary to ban RAND commitments, but it is important to be sure that the competition laws do not stand in the way of more specific royalty disclosures so long as standard precautions are taken to assure that any discussions involving those disclosures do not wander into discussions about the prices of products and services incorporating the standard.

\footnotetext{
${ }^{133}$ Damien Geradin, et al., The Ex Ante Auction Model for the Control of Market Power in Standard Setting Organizations, CEMFI Working Paper 0703 (May 2007), available at ftp://ftp. cemfi.es/wp/07/0703.pdf.

${ }^{134}$ Majoras, supra note 38, at 10 ("Joint ex ante royalty discussions, of course, can offer an opportunity for SSO members to reach side price-fixing agreements that are per se illegal.”).

${ }^{135}$ For a useful summary of such precautions, see Gray, supra note 51.
} 
Open Access This chapter is licensed under the terms of the Creative Commons Attribution 4.0 International License (http://creativecommons.org/licenses/by/4.0/), which permits use, sharing, adaptation, distribution and reproduction in any medium or format, as long as you give appropriate credit to the original author(s) and the source, provide a link to the Creative Commons license and indicate if changes were made.

The images or other third party material in this chapter are included in the chapter's Creative Commons license, unless indicated otherwise in a credit line to the material. If material is not included in the chapter's Creative Commons license and your intended use is not permitted by statutory regulation or exceeds the permitted use, you will need to obtain permission directly from the copyright holder.

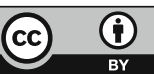

